\title{
Recurrent Pneumonia Caused by The Aspiration of a Quad Dental Prosthesis, Late Diagnosed and Treated with Rigid Bronchoscopy
}

\author{
Geç Tanı Konan ve Rijid Bronkoskopi ile Tedavi Edilen Dörtlü Diş \\ Protezinin Aspirasyonuna Bağlı Gelişen Tekrarlayıcı Pnömoni
}

Hüseyin Lakadamyalı', Berna Devrim Yağbasan', Tülay Kıvanç²

\begin{abstract}
Foreign body aspiration is a very serious and critical problem. It may cause chronic and irreversible lung injury and occasionally lead to sudden death. Early diagnosis is key to the prevention of complications. Although the aspiration of teeth and dental repairs is a recognized event, it is only rarely reported in the literature. The main reasons for aspiration are maxillofacial trauma, dental treatment procedures or alcohol/ethanol intoxication and dementia. We report a case of dental treatment the lead to aspiration of a quad dental prosthesis, with delayed diagnosis and complications.
\end{abstract}

Key words: Foreign body aspiration, pneumonia, bronchoscopy.

\section{Özet}

Yabancı cisim aspirasyonu çok ciddi ve yaşamsal bir sorundur. Akciğerlerde geriye dönüşümsüz - kronik hastalıklara hatta bazen ani ölümlere neden olabilir. Erken tanı komplikasyonların önlenmesinde anahtardır. Diş ve ağız içi tedavi süreçlerine bağlı aspirasyon bilinen ancak, literatürde çok sık bildirimi yapılmayan durumlardır. Aspirasyonların esas nedenleri maksillofasiyal travmalar, ağız içi tedavi süreçleri veya alkol/etanol zehirlenmesi ile demansa bağlıdır. Bu makalede geç tanı konulan ve komplikasyona yol açan, ağız içi tedavi esnasında gelişen dörtlü diş protezi aspirasyonu olgusu sunulmuştur.

Anahtar Sözcükler: Yabancı cisim aspirasyonu, pnömoni, bronkoskopi.

'Department of Chest Diseases, Başkent University Alanya Research and Training Center, Antalya, Turkey

${ }^{2}$ Department of Chest Diseases, Başkent University Konya Research and Training Center, Konya, Turkey

'Başkent Üniversitesi Alanya Uygulama ve Araşııma Merkezi, Göğüs Hastalıkları Bölümü, Antalya

${ }^{2}$ Başkent Üniversitesi Konya Uygulama ve Araştırma Merkezi, Göğüs Hastalıkları Bölümü, Konya

Submitted (Başvuru tarihi): 10.07.2015 Accepted (Kabul tarihi): 25.08.2015

Correspondence (iletişim): Hüseyin Lakadamyalı, Department of Chest Diseases, Başkent University Alanya Research and Training Center, Antalya, Turkey

e-mail: lakadamyali.h@gmail.com 
Foreign body aspiration is a very serious and critical problem. It may cause chronic and irreversible lung injury and sometimes leads to sudden death. Early diagnosis is key to the prevention of complications. The National Safety Council of America cited the inhalation of foreign bodies, as a leading cause of accidental death at home in children under six years of age (1). Aspiration of teeth and dental restorations is a recognized, yet a rare event in the literature. Main reasons for aspiration are maxillofacial trauma, dental treatment procedures or alcohol/ethanol intoxication and dementia (2). We report a case of dental treatment leading to aspiration of a radiolucent quad dental prosthesis, with delayed diagnosis and complications.

\section{CASE}

A 53-year-old male, presenting with progressive complaints of coughing, sputum production, fever and dyspnea ongoing for two weeks was hospitalized and prediagnosed with pneumonia. The patient had been previously diagnosed with recurrent pneumonia over the past few years. He had been treated for pulmonary tuberculosis two years before and was a heavy smoker. At the physical examination, we auscultated crackles under the scapula at the left and the right pulmonary base and bilateral strong expiratory rhonchi. Clinical findings were as follows: $\mathrm{SpO}_{2}: 90 \%$, respiratory rate: $28 / \mathrm{min}$, and pulse: $78 / \mathrm{min}$ blood pressure: $125 / 75 \mathrm{mmHg}$. On chest radiography infiltration of the left basal zone was seen (Figure 1). Laboratory findings showed white blood cell (WBC): 20,300 K/mm 3 , CRP: $117 \mathrm{mg} / \mathrm{L}$, sedimentation rate: 61 $\mathrm{mm} /$ hour. Intermediate grade obstruction was determined using a pulmonary function test. Because of the patient's pneumonia history, he underwent a high-resolution thorax CT (HRCT) prediagnosed with bronchiectasis. He was treated with parenteral ampicillin-sulbactam (SAM) 4 $\mathrm{gr} /$ day, oral levofloxacin $500 \mathrm{mg} /$ day, parenteral steroids, short acting 32 -agonists and short acting anticholinergic nebules, with the diagnosis of pneumonia together with an exacerbation of his COPD.

At the HRCT examination a radiolucent suspect irregular bordered lesion at the entrance of the left main bronchus, not far from the main carina, was seen (Figure 2). Therefore, we decided to perform a fiberoptic bronchoscopy (FOB) under sedation. A flaring yellow colored mass was seen at the entry of the left main bronchus. The mass could not move by $F O B$, therefore the procedure was changed to rigid bronchoscopy under general anesthesia. The mass was taken out by rigid bronchoscopy and shown to be a quad dental prosthesis (Figure 3). A punch biopsy was taken from the lesion. After this procedure, the patient was questioned again and it was ascertained that he had swallowed the dental prosthesis during dental treatment four years earlier. The patient asserted that his dentist told him that the prosthesis had progressed to the stomach and it would cause no harm. It is probable that the patient was not able to recognize the aspiration of his prosthesis due to the local anesthesia during the dental treatment. It was understood that during a period of four years patient was admitted to different hospitals and treated several times for recurrent pneumonias (twice a year) and three times during the last year for exacerbation of COPD due to this aspiration. The chest radiograph and thorax $\mathrm{CT}$ taken after his treatment showed no signs of infiltration or any endobronchial lesion.

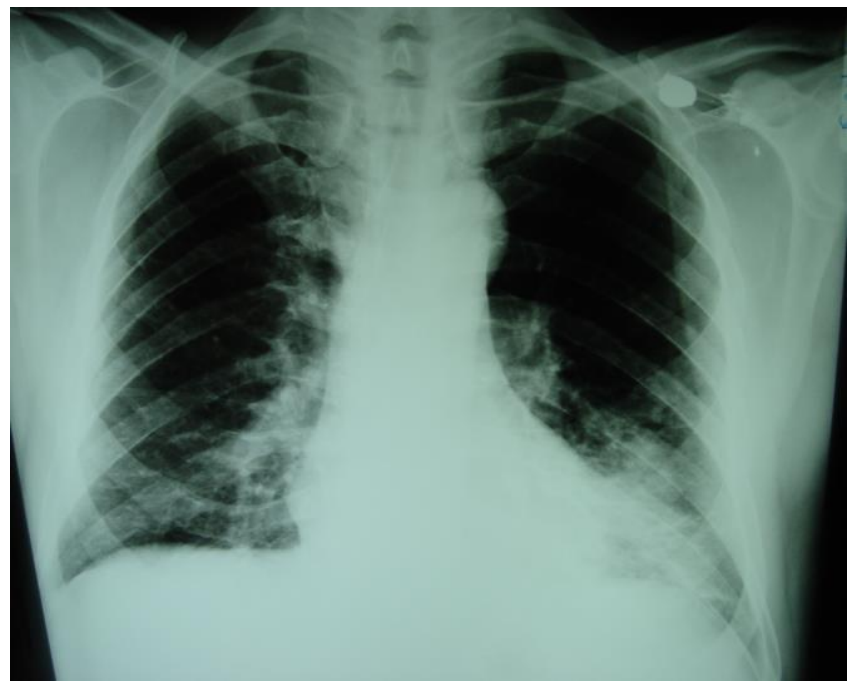

Figure 1: Chest radiograph: Infiltration of the left basal zone

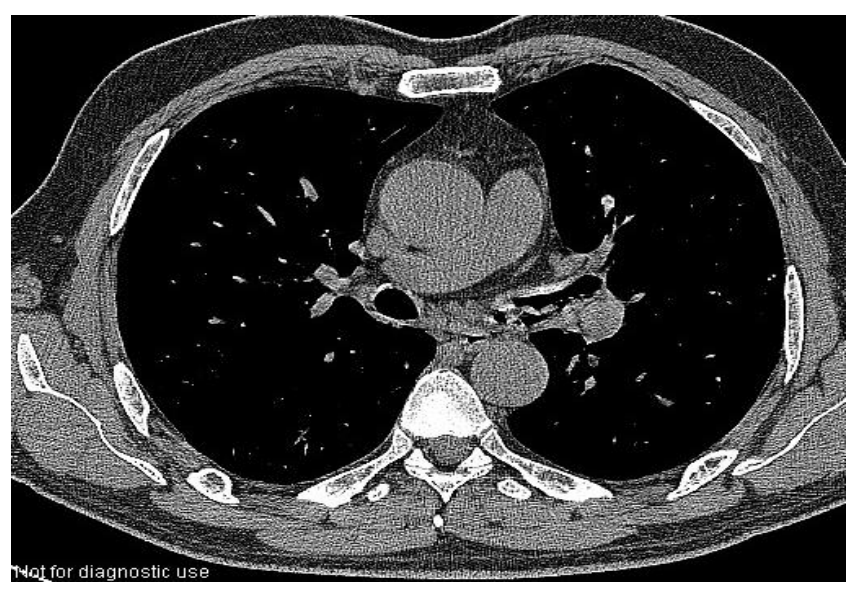

Figure 2: HRCT: A soft tissue density irregular bordered lesion at the entrance of the left main bronchus

\section{DISCUSSION}

The aspiration of foreign materials is a serious cause of mortality and morbidity in all age groups. Predisposing 
factors include young and old age, maxillofacial traumas and alcohol consumption. While acute developing respiratory changes precipitate early diagnosis, subacute developing respiratory problems and the lack of a radioopacity at a radiologic investigation, can delay the diagnosis. The dental prosthesis of our patient was made of methyl methacrylate. Since this material has a radiolucent feature, the prosthesis was not seen at radiographs and led to delayed diagnosis.

When recurrent infections at the same anatomic location are seen, local obstruction due to tumors or foreign bodies must be kept in mind as a causative factor. Further diagnostic evaluation with bronchoscopy must not be delayed. Studies have shown that bronchoscopy is superior to radiographs when there is a suspicion foreign material have been aspirated $(3,4)$. Late diagnosis of foreign material aspiration, due to the aspiration of a dental prosthesis is rarely encountered in the literature (5). In our case, the diagnosis was obtained quite a long time after the aspiration event (four years).

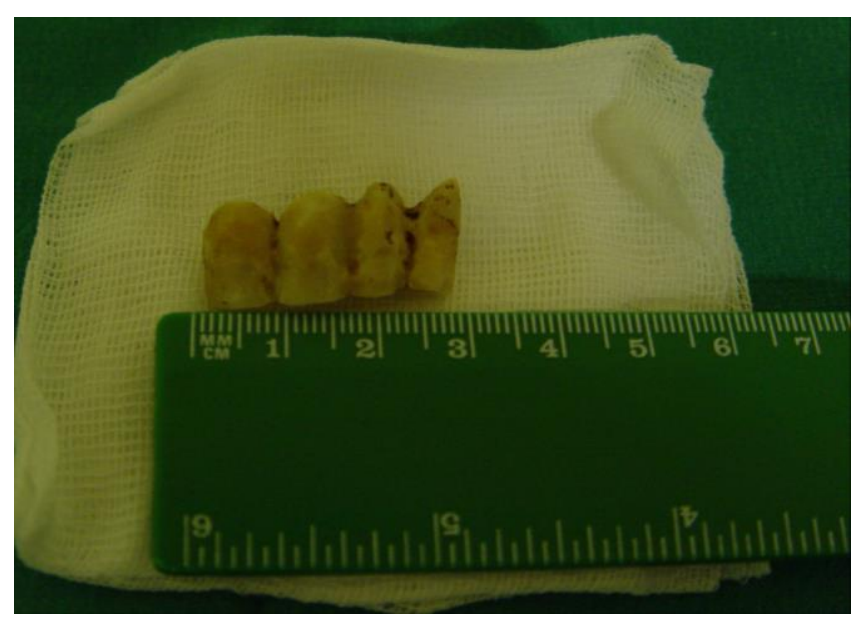

Figure 3: Extracted a quad dental prosthesis

Fiberoptic bronchoscopy, to see local bronchial obstruction, must unquestionably be performed in middle and advanced aged patients with recurrent pneumonia and a smoking history. Rigid bronchoscopy under general anesthesia is regarded as the procedure of choice for the removal of aspirated foreign material (6).

Any coughing and dyspnea like symptoms following dental treatment should be taken seriously by dentists, and their patients must be specifically questioned about these complaints. It must also be held in mind that foreign bodies do not always show radioopacity.

Foreign body aspiration is serious and potentially fatal. Early diagnosis is key to the prevention of complications like pneumonia. Correct interpretation and assimilation of the medical history, physical examination and radiographic evaluation are necessary to achieve an early diagnosis of foreign-body aspiration. The procedure of choice for the removal of aspirated big foreign bodies is rigid bronchoscopy under general anesthesia.

\section{CONFLICTS OF INTEREST}

None declared.

\section{AUTHOR CONTRIBUTIONS}

Concept - H.L., B.D.Y., T.K.; Planning and Design - H.L., B.D.Y., T.K.; Supervision - H.L., B.D.Y., T.K.; Funding H.L.; Materials - H.L., B.D.Y.; Data Collection and/or Processing - H.L., B.D.Y.; Analysis and/or Interpretation H.L., T.K.; Literature Review - B.D.Y., T.K.; Writing - H.L., B.D.Y., T.K.; Critical Review - H.L.

\section{YAZAR KATKILARI}

Fikir - H.L., B.D.Y., T.K.; Tasarım ve Dizayn - H.L., B.D.Y. T.K.; Denetleme - H.L., B.D.Y., T.K.; Kaynaklar - H.L.; Malzemeler - H.L., B.D.Y.; Veri Toplama ve/veya İşleme H.L., B.D.Y.; Analiz ve/veya Yorum - H.L., T.K.; Literatür Taraması - B.D.Y., T.K.; Yazıyı Yazan - H.L., B.D.Y., T.K.; Eleştirel İnceleme - H.L.

\section{REFERENCES}

1. Puhakka H, Svedström E, Kero P, Valli P, lisalo E. Tracheobronchial foreign bodies. A persistent problem in pediatric patients. Am J Dis Child 1989; 143:543-5.

2. Baharloo F, Veyckemans F, Francis C, Biettlot MP, Rodenstein DO. Tracheobronchial foreign bodies: presentation and management in children and adults. Chest 1999; 115:1357-62. [CrossRef]

3. Pinto A, Scaglione M, Pinto F, Guidi G, Pepe M, Del Prato $B$, et al. Tracheobronchial aspiration of foreign bodies: current indications for emergency plain chest radiography. Radiol Med 2006; $111: 497-506$. [CrossRef]

4. Zerella JT, Dimler M, McGill LC, Pippus KJ. Foreign body aspiration in children: value of radiography and complications of bronchoscopy. J Pediatr Surg 1998; 33:16514.

5. Başoğlu OK, Buduneli N, Çağırıcı U, Turhan K, Aysan T. Pulmonary aspiration of a two-unit bridge during a deep sleep. J Oral Rehabil 2005; 32:461-3. [CrossRef]

6. Hasdiraz L, Oguzkaya F, Bilgin M, Bicer C. Complications of bronchoscopy for foreign body removal: experience in 1,035 cases. Ann Saudi Med 2006; 26:283-7. 